ENTREPRENEURSHIP AND SUSTAINABILITY ISSUES

ISSN 2345-0282 (online) http://jssidoi.org/jesi/

2020 Volume 7 Number 3 (March)

http://doi.org/10.9770/jesi.2020.7.3(65)
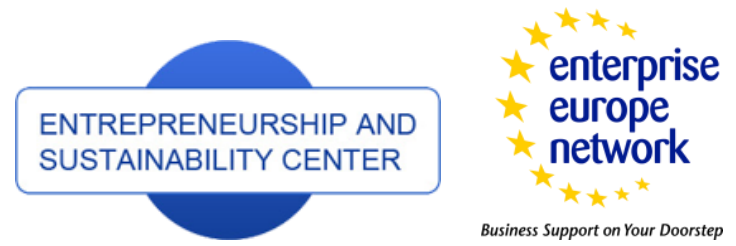

CASPA Scopus:

Publisher

Business Support on Your Doorstep

1 Clarivate

Analytics

$\underline{\text { http://jssidoi.org/esc/home }}$

\title{
THE IMPACT OF ABSORPTIVE CAPACITY AND INNOVATION AMBIDEXTERITY ON SUSTAINABLE COMPETITIVE ADVANTAGE: THE CASE OF INDONESIAN HIGHER EDUCATION*
}

\author{
Astadi Pangarso ${ }^{1}$, Endang Siti Astuti ${ }^{2}$, Kusdi Raharjo ${ }^{3}$, Tri Wulida Afrianty ${ }^{4}$ \\ 1,2,3,4 Brawijaya University, Faculty of Administrative Science, Business Administration Department, Jl. MT. Haryono, \\ Malang 65145, East Java, Indonesia \\ ${ }^{1}$ Telkom University, Faculty of Communication and Business, Business Administration Department, Jl. Telekomunikasi, \\ Terusan Buah Batu, \\ Bandung 40257, West Java, Indonesia
}

E-mails: ${ }^{1}$ astadipangarso@student.ub.ac.id; ${ }^{1}$ endangsiti@ub.ac.id; ${ }^{1}$ kusdi@ub.ac.id; ${ }^{1}$ twulidafia@ub.ac.id; 2astadipangarso@telkomuniversity.ac.id

Received 22 November 2019; accepted 24 February 2020; published 30 March 2020

\begin{abstract}
The purpose of this study is to empirically examine the mediation role of innovation ambidexterity on the impact of absorptive capacity on sustainable competitive advantage from the previous researchers' data article publication. A survey of academic and nonacademic staff from sixty four private higher education institutions (PHEIs) in Bandung, West Java, Indonesia was conducted for the research. A total of five hundred and thirty completed questionnaires from 478 academic and 52 non academic staff were statistically analyzed using SPSS and smart PLS. Investigating sustainable competitive advantage related issues for PHIEs in Indonesia is important for a number of reasons, including supporting the vision of the Golden Indonesia generation 2045. Moreover, the impact of absorptive capacity on sustainable competitive advantage in the literature is remains unclear, thus a new theoretical framework is needed related to the concept of ambidexterity. The finding of this research shows that innovation ambidexterity partially mediates the effect of absorptive capacity on sustainable competitive advantage as proposed in the hypothesis. The implications of this study are discussed.
\end{abstract}

Keywords: absorptive capacity; innovation ambidexterity; sustainable competitive advantage; non vocation private higher education institutions

Reference to this paper should be made as follows: Pangarso, A., Astuti, E.S., Raharjo, K., Afrianty, T.W. 2020. The impact of absorptive capacity and innovation ambidexterity on sustainable competitive advantage: the case of Indonesian higher education. Entrepreneurship and Sustainability Issues, 7(3), 2436-2455. http://doi.org/10.9770/jesi.2020.7.3(65)

JEL Classifications: M10, C12, C31, C83, C88, C93, D83, I23, N35

\footnotetext{
* This research was supported by LPDP (Indonesia Endownment Fund for Education) as a research funder and LPPM Telkom University as a publication funder, Indonesia
} 


\section{ENTREPRENEURSHIP AND SUSTAINABILITY ISSUES}

ISSN 2345-0282 (online) http://jssidoi.org/jesi/

2020 Volume 7 Number 3 (March)

http://doi.org/10.9770/jesi.2020.7.3(65)

\section{Introduction}

The industrial revolution 4.0 era, even society 5.0 (Salgues, 2018) characterized by dynamic organizational changes or VUCA (Volatility, Uncertainty, Complexity, Ambiguity) conditions (Xing, Liu, Boojihawon, \& Tarba, 2019) that have several impacts including: (1) business competition is getting tougher (Raharjo \& Fernandes, 2018). (2) There is a transformation of the business model from traditional business (Rahma, Astuti, Utami, Raharjo, \& Arifin, 2018). (3) Organizations must be able to adjust flexibly (Pangarso, 2014). (4) There is a critical role of knowledge (Shahriari, Abzari, Isfahani, \& Kianpour, 2018) so organizations can innovate (Raghuvanshi, Ghosh, \& Agrawal, 2019). If an organization has a competitive advantage, the organization can at least survive and excel in sustainable competition. Sustainable competitive advantage is influenced by the ability of an organization to absorb knowledge from outside organization to subsequently produce innovations simultaneously between incremental innovation (through the process of exploitation) and radical innovation ( through the process of exploration).

The theory that supports the impact of absorptive capacity on innovation is the dynamic capability theory (Teece, Pisano, \& Shuen, 1997). Absorptive capacity is part of dynamic capability itself (Zahra \& George, 2002). Conceptual research, which also strengthens the next empirical research on the direct influence of absorptive capacity on innovation, have been done by Jurksiene \& Pundziene (2016). Jurksiene \& Pundziene (2016) suggested the need for empirical research on the direct impact of absorption capacity on innovation.

The direct impact of innovation on competitiveness is accordance with the theory of absorptive capacity (Cohen \& Levinthal, 1990). Schumpeter (2003) also strengthen by stating that innovation is the cause of competitive advantage. Previous research by Preda (2014) and Jurksiene \& Pundziene (2016) are conceptual research that produces a theoretical proposition that supports the relationship of the influence of innovation on competitive advantage.

This research is essential because it has implications both theoretically and practically. Theoretically, this research contributes to the body of knowledge because it enriches the empirical application of absorptive capacity theory and dynamic capability theory. Also, this research contributes to filling the research gap related to the impact of absorptive capacity \& innovation ambidexterity on sustainable competitive advantage (Pangarso et al., 2020).

The practical implications are motivated by practical problems, especially in the context of higher education (HE). President Joko Widodo prioritizes education as an essential sector in Indonesia's development (Biro Kerjasama dan Komunikasi Publik \& Kemenristekdikti, 2018). The republic of Indonesia 2019-2024 development theme is "superior human resources, Indonesia becomes a developed country"(Nasir, 2019). Indonesia's development theme can be achieved through education so as to create innovation and increase competitiveness (Keuangan, 2019a, 2019b). The topics of innovation and competitiveness are important topics for education in Indonesia. The total number of students in Indonesia in 2015 was 3.5 million (Afrianty, Burgess, \& Theodora, 2015), which continues to increase to a total of more than 7.5 million in November 2018 (Ismunandar, 2019). From the Indonesia's number of students' data further strengthens the importance of the education sector for the Indonesian people.

The number of private higher education institutions (PHEIs) entering the top 100 rankings position of tertiary higher education institutions is still small when compared to the public higher education institution. Also, there is no PHEI that has been placed in the top fourteen or first cluster. Higher education ranking position by Kemenristek Dikti (Indonesian higher education national institution) is essential and reflects the competitive advantage of a higher education institution (HEI) in Indonesia. This is due to the HEI ranking indicators used Kemenristek Dikti / Indonesian Ministry of Research, Technology and Higher Education (Kemenristekdikti, 


\section{ENTREPRENEURSHIP AND SUSTAINABILITY ISSUES}

ISSN 2345-0282 (online) http://jssidoi.org/jesi/

2020 Volume 7 Number 3 (March)

http://doi.org/10.9770/jesi.2020.7.3(65)

2018a; Pengetahuan, 2015), is part of the competitive advantage indicator (Organization \& Pannen, 2017). The HEI ranking is also in accordance with the RBV theory (Barney, 1991; Templin, 1999; Wernerfelt, 1984) because it consists of resources and capabilities possessed by HEI. These indicators include human capital, institutional performance, student activity performance, research performance, and community service and innovation performance.

In general, the number of PHEIs in Java Island (as the center island of Indonesian HEI) dominates HEI ranking in the non-vocational category. From the Indonesian HEI ranking indicators data obtained information that: (1) West Java province is a province with the largest population in Indonesia (Statistik, 2018) with a composition of the population that potentially requires higher education, which is also quite large (Jabar, 2016). (2) West Java Province is the province with the lowest number (only seven) for the non-vocational PHEI that is included in the 2019 ranking of higher education by Kemenristek Dikti comparing with the other three provinces in Java Island, while the total number of non-vocational PHEIs in the province of West Java is a 250.

The problem of higher education competitive advantage is also experienced by universities around the world regarding innovation and sustainability (Ávila et al., 2017; Girdzijauskaite et al., 2019).

Prof. Dr. Ir H. Eddy Jusuf Sp, M.Si., M.Kom knows the issue of PHEI's competitive advantage in West Java province. As Chief of APTSI Jabar (Indonesian Private Higher Education Institution Association) as well as the former Rector of Pasundan University, Bandung, he stated that: "there are only five PHEIs in West Java that are competitive." Prof. Dr. Ir. H. Eddy Jusuf Sp, M.Si., M.Kom statement through the well-known public media in West Java, namely Pikiran Rakyat newspaper in early 2018 (Seftiawan, 2018). There are seven non-vocational PHEIs in West Java province which is ranked 100 universities in Indonesia and all located in the Bandung area (Kemenristekdikti, 2018b; Koran Sindo, n.d.). Then the Bandung area deserves to represent the PHEI of West Java province.

Practically this research contributes to PHEIs decision makers in Indonesia to improve sustainable competitive advantage. Increasing sustainable competitive advantage for PHEIs in Indonesia is vital because contributing to increasing the ranking position of a PHEI, and it is also for a more extensive scope to provide to the preparatory steps to realize the vision of the Golden Indonesia generation 2045 (Nasional/Bappenas, 2019) .

Previous research by Enkel, Heil, Hengstler, \& Wirth (2016); Justin J.P. Jansen, (2005); Kohlbacher, Weitlaner, Hollosi, Grahsl, \& Gru (2013); Limaj \& Bernroider (2017); Noni, Ganzaroli, Orsi, \& Roberta (2013); Zou et al. (2018) examined the impact of absorptive capacity on innovation partially (between the four sub-variables of absorption capacity on two of the innovation sub-variables) but have not examined innovation from the perspective of ambidexterity. These previous research have limitation because it is done for a limited context and country, so research needs to be done in different industrial sectors and or countries.

Preda (2014) and Jurksiene \& Pundziene (2016) research limitations are not yet done empirically testing related to the impact of innovation ambidexterity on competitive advantage. Preda (2014) states that theoretically, there is a relationship between the impacts of innovation exploration capabilities and the innovation exploitation capabilities on competitive advantage. What distinguishes between the research conduct by Preda (2014) and Jurksiene \& Pundziene (2016) is if Jurksiene \& Pundziene (2016) examine the impact of dynamic capability on competitive advantage mediated by organizational ambidexterity not by innovation ambidexterity. Because innovation ambidexterity is part of organizational ambidexterity, it is based on research Preda (2014) can be logically related that innovation ambidexterity affects sustainable competitive advantage.

This research fills the research gap from Rao \& Thakur (2019) because it is an empirical study of ambidexterity construct for knowledge workers, where the respondents of this study are the people in the formal knowledge 


\section{ENTREPRENEURSHIP AND SUSTAINABILITY ISSUES}

ISSN 2345-0282 (online) http://jssidoi.org/jesi/

2020 Volume 7 Number 3 (March)

http://doi.org/10.9770/jesi.2020.7.3(65)

(HEI) environment, namely lecturers (A. Pangarso, 2016). Innovation ambidexterity is a part of the ambidexterity construct that is tested to improve sustainable competitive advantage.

What distinguishes this theoretical framework with previous research are: (1) this research simultaneously links the exploration of innovation and the exploitation of innovation while its predecessor research only connects one of exploration or exploitation. (2) Study conducted by Enkel et al. (2016); Justin J.P. Jansen (2005); Kohlbacher et al. (2013); Limaj \& Bernroider (2017); Noni et al. (2013) about the impact of absorptive capacity on innovation is not in different contexts with this research, so this empirical research is expected to contribute to the generalization of theories. (3) This study aims to build and empirically test a new theoretical framework developed by the construct of absorptive capacity, innovation ambidexterity that affects the sustainable competitive advantage that has never been done before for the context of Indonesian non vocation PHEIs as a country with great potential to become one of the developed countries in Asia using multi-respondent. (4) The theoretical framework tested in this study clarifies the process of the impact and prediction of absorptive capacity on sustainable competitive advantage (Pangarso et al., 2020).

Higher education governance in Indonesia has adopted business process principles (Republic Indonesia, 2019). Therefore, it is appropriate for this research to use theories and constructs from the business literature. The research question is, "Does innovation ambidexterity mediate the impact of absorptive capacity on sustainable competitive advantage?". The organization of this paper consists of introduction, literature review, research method, results, discussion, and conclusion. The introduction describes the importance of this research, both theoretically and practically. The originality of this research and the research gap from previous empirical research on this topic are also identified in the introduction section. The literature review puts emphasis on the relevant theories as the basis for the hypotheses development. The research methods explain the data collection method as well as the data analysis. The results section provides the data analysis results, both descriptive statistics and hypothesis testing results. The discussion section provides the interpretation and the significance of the findings related to the research problem and the hypotheses. Lastly, the summary of the research findings and identification of the research limitations as well as some future research agenda were stated in the conclusion section of this paper.

\section{Literature Review}

\section{Theory}

The general theory underlying competitive advantage was first stated by Porter (1985), namely the five forces theory. Porter's theory of competitive advantage tends to use a macro perspective (industry). Next comes the approach of competitiveness that tends to focus more internally first by paying attention to the resources and capabilities of an organization. Beginning with Resource-Based View theory (RBV) (Wernerfelt, 1984), which states that to achieve a competitive advantage, an organization must pay attention and optimize its resources followed by the concept of Sustainable Competitive Advantage by Barney (1991), which states that to achieve a sustainable competitive advantage, specific resources and capabilities are needed VRIN (Valuable, Rare, Inimitability, Nonsubstitute).

Furthermore, by changing of organizational environments that are increasingly dynamic, new theories emerge, which is named "dynamic capability" (Teece, Pisano, \& Shuen, 1997). This theory states that organizations must be able to build, integrate, and configure internal and external capabilities to be able to produce new capabilities to respond to environmental dynamics. 


\title{
ENTREPRENEURSHIP AND SUSTAINABILITY ISSUES
}

ISSN 2345-0282 (online) http://jssidoi.org/jesi/

2020 Volume 7 Number 3 (March)

http://doi.org/10.9770/jesi.2020.7.3(65)

\section{Sustainable Competitive Advantage}

Competitive advantage is different from sustained or sustainable competitive advantage. The difference is in terms of the imitation of the unique strategies and values used by business organizations. Sustainable competitive advantage is competitiveness that cannot or is very difficult for competitors to imitate (Barney, 1991).

\section{Innovation Ambidexterity}

Innovation is crucial because it is a source of competitive advantage (Preda, 2014). The innovations discussed in this study are innovations from the concept of organizational ambidexterity. The idea of ambidexterity is still a concept that has not been established theoretically, so it opens up opportunities to continue to be used as research variables (Simsek, 2009). The idea of organizational ambidexterity is generally divided into two parts viz: structural ambidexterity (March, 1991) and contextual ambidexterity (Gibson \& Birkinshaw, 2004). S. Kortmann (2012) divides the concept of organizational ambidexterity into four types, namely structural, contextual, innovative, and sequential. If related to the dynamic capability theory which used in this study, the most appropriate for the organizational analysis unit is innovation ambidexterity. If the concept of ambidexterity, in general, is still open for research, then the more specific notion of innovation ambidexterity is even more transparent.

From various sources, innovation ambidexterity means, among others: (1) "ability to simultaneously pursue both incremental [exploitative] and discontinuous [exploratory] innovation" (Jansen, 2005); (2) "combining exploratory and exploitative innovations for sustainable superior performance" (Sebastian Kortmann, 2015); (3) "a firm's ability to concurrently develop explorative and exploitative capabilities for both radical and incremental innovation” (J. A. Zhang, Edgar, Geare, \& O'Kane, 2016); (4) “organisational actions of simultaneously leveraging exploratory innovation and exploitative innovation" (Zang \& Li, 2017); (5) "a combination of two types of innovation capability: explorative and exploitative capability” (Zhang \& Cui, 2017).

The concept of innovation from the perspective of ambidexterity is following the dynamic capability theory (Teece et al., 1997), which states that ambidexterity is part of dynamic capabilities (O'Reilly \& Tushman, 2008). The concept of innovation exploration has a radical characteristic of innovation, while the exploitation of innovation has the character of incremental innovation (Preda, 2014).

\begin{abstract}
Absorptive Capacity
Absorptive capacity is a theory put forward by W. M. Cohen \& Levinthal (1990) in Mariano \& Walter (2015; Miles, 2012). It is defined as "the firm's ability to recognize value, incorporate, and exploit new exogenous ideas" (Nowak, 2017) or the ability of an organization to recognize the value of new information that comes from outside, blend it, form a unique knowledge and apply it to important things directly related to the existence of innovation (Child, 2015). More precisely, absorptive capacity is 'a slice' between dynamic capability theory and knowledge-based theory (Vera, Crossan, \& Apaydin, 2003). The absorptive capacity theory states the importance of absorbing knowledge from outside the organization so that organizations can be flexible and innovative to improve performance (Miles, 2012) and competitive advantage.

Based on Apriliyanti \& Alon (2017) stated that the topic of absorptive capacity research is a fascinating topic to be studied can be known from the increasing trend from 1990 to 2015, reaching nearly 3500 publications on the topic. Absorptive capacity entered the top ten research topics in 2015 (Mariano \& Walter, 2015). Even if it is related to innovation, which is an absorptive capacity outcome (Zou et al., 2018), then the topic of absorption capacity ranks first in the discussion of innovation (Saatçioğlu, Çaylan, \& Ozeren, 2016).
\end{abstract}




\section{ENTREPRENEURSHIP AND SUSTAINABILITY ISSUES}

ISSN 2345-0282 (online) http://jssidoi.org/jesi/

2020 Volume 7 Number 3 (March)

http://doi.org/10.9770/jesi.2020.7.3(65)

\section{Hyphoteses Development}

The direct impact of absorptive capacity on innovation ambidexterity is based on dynamic capability theory (Teece et al., 1997). Ambidexterity innovation is an outcome of absorptive capacity (Jansen, 2005). Absorptive capacity enables organizations to be able to innovate through exploration (radical) and exploitation (incremental) simultaneously (M. Zhang, Zhao, \& Lyles, 2018). Klinger (2016), through his literature review, concluded that the higher the absorptive capacity, the more simultaneous explorative and exploitative innovations would be.

Absorptive capacity is the antecedent of organizational ambidexterity (Mardi, Arief, Furinto, \& Kumaradjaja, 2016). The five previous studies by Enkel et al. (2016), Jansen (2005), Kohlbacher et al. (2013), Limaj \& Bernroider (2017) dan Noni et al. (2013) were linking the absorption capacity of innovation partially (between the absorption sub-variables of the innovation sub-variable) not simultaneously. Justin J.P. Jansen (2005) stated that the interaction of absorptive capacity affects the increased exploration of innovation for the scope of units in an organization. While Enkel et al. (2016) examine the impact between sub variable absorptive capacity on innovation sub-variables with individual analysis units.

The identification have a positive impacts on both the exploitation and exploration of innovation while assimilation has a positive impact only on innovation exploration. Limaj \& Bernroider (2017) examine the impact of sub variable absorptive capacity on innovation sub-variables. For the research agenda of the three upcoming studies above, it is suggested research for different industrial domains and or countries, and this opens a gap for researching the Indonesian domain of non vocational PHEIs. The impact of absorptive capacity on innovation ambidexterity is the agenda of future empirical research Jurksiene \& Pundziene (2016).

H1: Absorptive capacity has a positive impact on innovation ambidexterity.

The direct influence of innovation ambidexterity on sustainable competitive advantage, including dynamic capability theory (Teece et al., 1997) and supported by statements O'Reilly \& Tushman (2008) that ambidexterity is a form of dynamic capability. An organization's competitiveness is influenced by innovation (Nora et al., 2016). Previous research also supports empirical research related to the impact of innovation on competitive advantage, among others by Preda (2014) and Jurksiene \& Pundziene (2016). Both of these studies are conceptual studies that produce theoretical propositions that support the impact of innovation on competitive advantage. Future research agenda of Preda (2014) and Jurksiene \& Pundziene (2016) suggest that research be carried out both theoretically and empirically related to the impact of ambidexterity on competitive advantage.

H2: Innovation ambidexterity has a positive impact on sustainable competitive advantage.

The indirect impact of absorptive capacity on sustainable competitive advantage is mediated by innovation ambidexterity based on dynamic capability theory (Teece et al., 1997). This indirect impact is a consequence of the two previous hypotheses.

H3: Innovation ambidexterity mediates the positive impact of absorptive capacity on sustainable competitive advantage. 


\section{Theoretical framework}

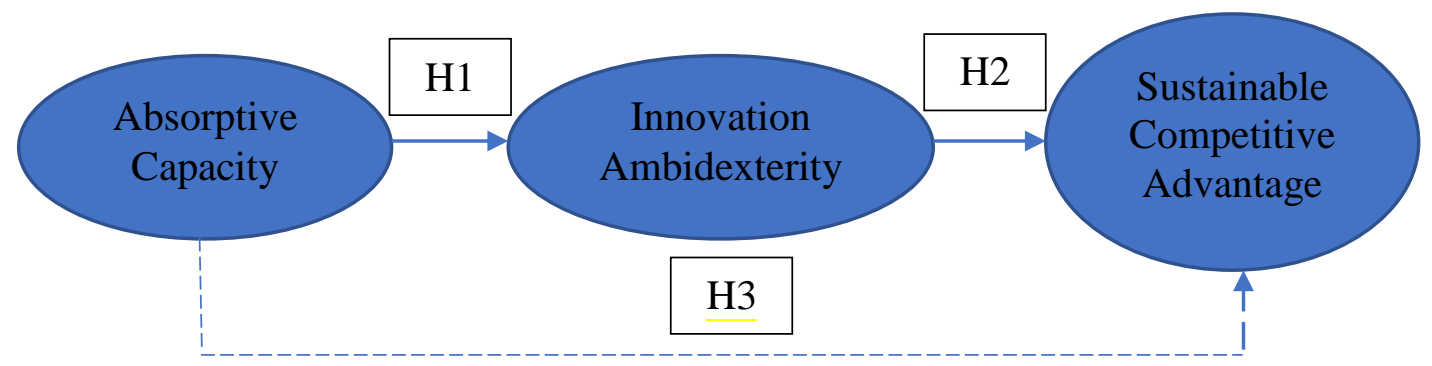

Fig.1. Theoretical framework

Source: (Pangarso et al., 2020)

\section{Research Method}

This empirical research examines our theoretical framework (Pangarso et al., 2020) based on the collected data in 2019. Thus, this research is considered as an explanatory research that explains the impact among variables studied or commonly referred to as causal research (Newhart \& Patten, 2018).

The population of this research is all the non-vocational PHEIs in Bandung area representing West Java province with the total of eighty-one (81) PHEIs. Based on conformity with the background of the study (practical and theoretical problems), the representation of the sample to the population, the ease, accuracy, and availability of data (Newhart \& Patten, 2018). The determination of the type of sample method is based on conformity with the background of the study (practical and theoretical problems), the representation of the sample to the population, and the ease, accuracy, and availability of data (Cresswell, 2014).

Each PHEI is represented by at least three categories of respondents representing the PHEI organizations. It is expected that these three categories of respondents can provide a complete perception of the measurement of all research variables. The three types are academic leaders, lecturers, and quality assurance employees (non academic staff). This categorization includes multiple respondent with a purpose: (1) bias minimalization (Burton, Eriksen, Håkonsson, Knudsen, \& Snow, 2008; S. Kortmann, 2012; Li, 2013; Liao, Welsch, \& Stoica, 2003; Prajogo \& Oke, 2016; Soto-Acosta, Popa, \& Martinez-Conesa, 2018); (2) increasing validity (Valmohammadi \& Ahmadi, 2015), reliability (Blarr, 2012) also (3) provide higher generalization of data processing results (Martinez-Conesa, Soto-Acosta, \& Carayannis, 2017). The categorization of respondents with multiple respondents for the university organizational analysis unit has also been carried out by Chang et al. (2016), where one university organization was represented by five lecturers and four heads of administration. Furthermore, the three categories are limited to the conditions of having fulltime employee status for a minimum of three years of work, with the consideration that it will provide more understanding and appropriate answers to the data collected. "Fulltime" definition is working at least 40 hours a week (Menteri Riset \& Pendidikan Tinggi, n.d.).

On average, one organization is represented by ten respondents of academic staff and non academic staff (three leaders, five lecturers, and two quality assurance). The leaders consist of 1 rector/vice rector, one dean/vice dean, and one head of study program. Fulltime lecturers with the most composition because lecturers are crucial for HEI (Pangarso, 2016; Pangarso, 2019b). The total number of respondents can be seen in Pangarso et al. (2020) which is total 810 . 
Processing questionnaire data using descriptive statistics (SPSS) and SEM PLS (smart PLS 3.2.9). Smart PLS used with consideration, among others (Hair, Hult, Ringle, \& Sarstedt, 2017) (Ringle et al., 2015) (Pangarso et al., 2020):

1. Can be used to structure complex theoretical models (consisting of many indicators).

2. Can be used for small sample sizes and for data that are not normally distributed.

3. Can be used to test both of explanatory and prediction relationship between variables.

Data collected through a survey using a questionnaire consisting of two parts. The questionnaire consist two parts, the first part aims to determine the characteristics of respondents and the second part aims to determine the perception of respondents regarding research variables. The questionnaire data can be found at supplementary material in appendix (Pangarso, 2019c) in Pangarso et al. (2020).

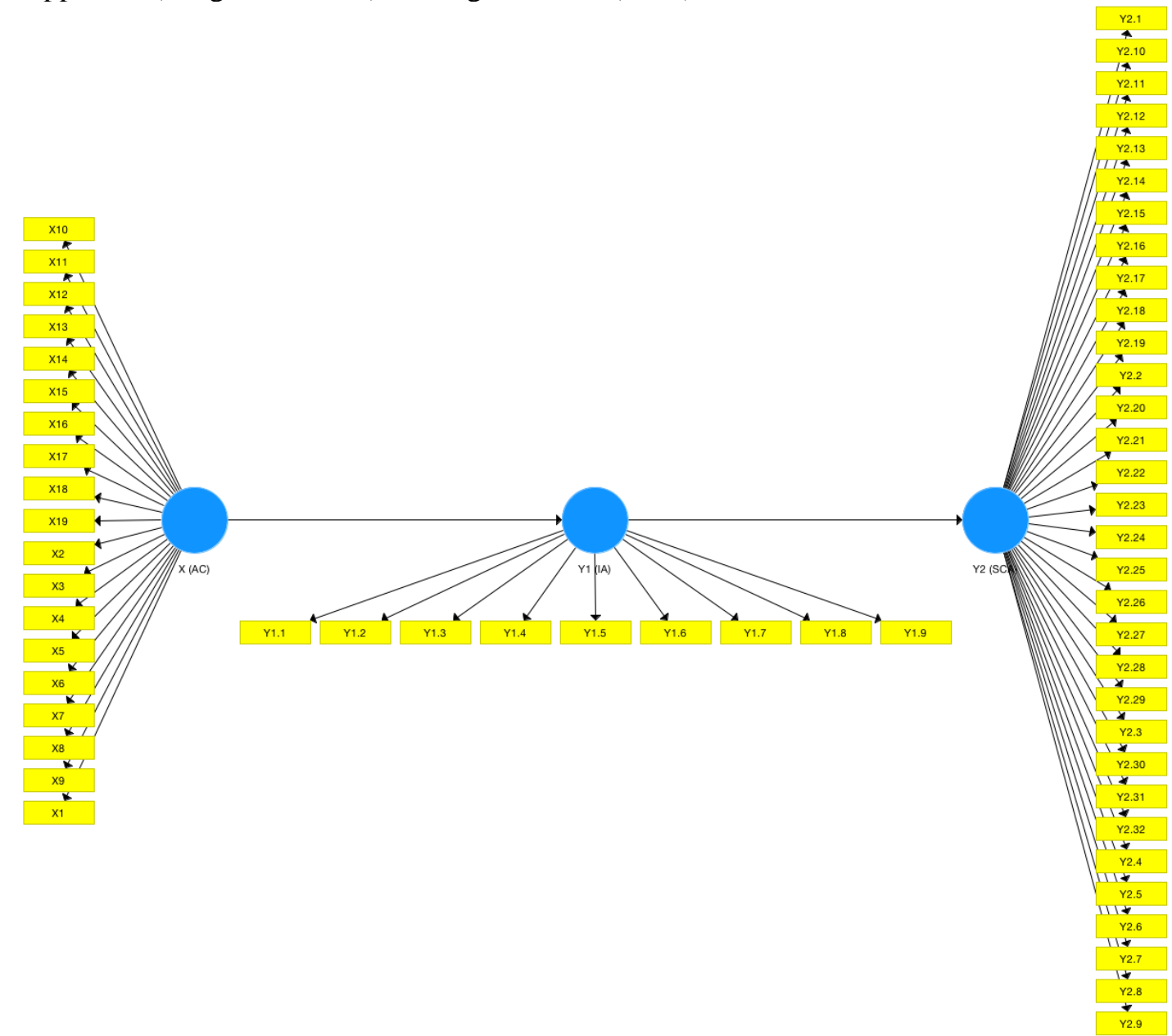

Fig. 2. Smart PLS theoretical framework Source: smart PLS data processing 


\section{ENTREPRENEURSHIP AND SUSTAINABILITY ISSUES}

ISSN 2345-0282 (online) http://jssidoi.org/jesi/

2020 Volume 7 Number 3 (March)

http://doi.org/10.9770/jesi.2020.7.3(65)

\section{Results}

From eight hundred and ten questionnaires distributed to eighty one PHEIs in the Bandung area, five hundered and thirty questionnaires from sixty-four PHEIs that were eligible to be collected. The first part of research questionnaire had the respondents' characteristics such as: dominated by men with a number that tends to be balanced with women; dominated by masters' degree far more than 50\% compared to bachelor and $\mathrm{PhDs}$ '; dominated by respondents whose had structural position more than $75 \%$ and dominated by lecturers and academic leaders compared to quality assurance position for more than $80 \%$. The amount of sample data collected has exceeded the minimum requirements required by smart PLS (Pangarso et al., 2020). The data are collected from 64 organizations of non-vocational PHEIs and has been meet the Smart PLS minimum sample requirement (Hair et al., 2017). The response rate respondents' questionnaire data collection is more than 65\% (Pangarso et al., 2020).

This research questionnaire is self-administrated/self-report (Fernando \& Chukai, 2018; Lee \& Fernando, 2015). Self-report means that research respondents filled out questionnaires based on their perception of the research variables at the institution where the person concerned worked. Self-report questionnaires can potentially lead to a common method bias. Therefore this questionnaire has gone through a pre-test, pilot test process and needs to be checked whether this research is free from the common method bias (Pangarso et al., 2020). A pre-test is used the expert assessment. The experts are three academician and Ph.D qualification consist of: 1 Professor, 1 Associate Professor and 1 Assistant Professor from related business administration field. After pass the expert judgement, the process continue with the pilot test to check the instruments validity and reliability using SPSS for 40 respondents from 40 non-vocational PHEIs. All of research indicators are valid (the research indicators $r$-value are more than r-table which is 0.320 ) and reliable (Cronbach'S alpha value is 0.985). Evaluation of common method variance using the Harman single factor test has been carried out (Podsakoff, MacKenzie, \& Podsakoff, 2012), and a variance value below $50 \%$ is obtained, the results of the SPSS calculation can be seen in Pangarso et al. (2020) and show that all research indicator are free from bias.

Data for respondents' perceptions, smart PLS measurement also structural model processing results on the second part questionnaire can be seen in Pangarso et al. (2020). Smart PLS process begins from evaluating the measurement model (outer model) consist: internal consistency reliability, indicator reliability, convergent validity, and discriminant validity (Hair et al., 2017) in Pangarso et al. (2020). The results of indicators which pass the the run the show of thumb assessment of internal reliability, construct validity, and discriminant validity can be seen within the table 2 .

Table 2. Research variable pass the smart PLS measurement model rule of thumb

\begin{tabular}{|l|l|}
\hline Variable & \multicolumn{1}{|c}{ Description of Indicator Item } \\
\hline \multirow{5}{*}{ Absorptive Capacity } & Frequency of cooperation with other organizations (X3.) \\
\cline { 2 - 3 } & The impactiveness of the competency improvement program internally (X4.) \\
\cline { 2 - 3 } & The ability to assimilate new technology and innovation (X5.) \\
\cline { 2 - 3 } & The ability to use various knowledge, competencies, and experience (X6.) \\
\cline { 2 - 3 } & Ability to develop knowledge management programs (X10.) \\
\cline { 2 - 3 } Innovation Ambidexterity & The importance of the ability to respond to competitive pressures (X12.) \\
\cline { 2 - 3 } & Ability to adjust the designed technology (X13.) \\
\cline { 2 - 3 } & Transfer of scientific and technological information (X14.) \\
\cline { 2 - 3 } & The ability to coordinate and integrate all stages of the R\&D process (X15.) \\
\cline { 2 - 3 } & Organizations can use and exploit new knowledge from the outside of organization (X16.) \\
\cline { 2 - 3 } & Priority use of technological knowledge and experience (X17.) \\
\cline { 2 - 3 } & Organizational awareness of its competence in innovation (X19.) \\
\cline { 2 - 3 } & Innovation in the quality of research and knowledge transfer (Y1.5.) \\
\hline &
\end{tabular}




\begin{tabular}{|c|c|}
\hline & Incrementally improve the quality of research and knowledge transfer (Y1.6.) \\
\hline & Incrementally increasing efficiency (Y1.7.) \\
\hline & Incrementally increasing the reliability of research results and knowledge transfer (Y1.8.) \\
\hline & Incrementally increasing automation in research operations and knowledge transfer (Y1.9.) \\
\hline \multirow{9}{*}{$\begin{array}{c}\text { Sustainable Competitive } \\
\text { Advantage }\end{array}$} & VRIN (Valuable, Rare, Imitability, Nonsubstitute) information management system (Y2.9.) \\
\hline & $\begin{array}{l}\text { The presence of international students has fulfilled the minimum requirements of the Ministry of Research, } \\
\text { Technology and Higher Education related to tertiary ranking (Y2.17.) }\end{array}$ \\
\hline & The ability of universities in marketing activities (Y2.18.) \\
\hline & ISO higher education certification (Y2.20.) \\
\hline & The ability of universities to design competitive organization (Y2.21.) \\
\hline & $\begin{array}{l}\text { The number of student achievements has met the minimum requirements of the Ministry of Research, } \\
\text { Technology and Higher Education related to non vocation HEI ranking (Y2.24.) }\end{array}$ \\
\hline & $\begin{array}{l}\text { The performance of student organizations has met the minimum requirements of the Ministry of Research, } \\
\text { Technology and Higher Education related to non vocation HEI ranking (Y2.25.) }\end{array}$ \\
\hline & $\begin{array}{l}\text { The research performance has met the minimum requirements of the Ministry of Research, Technology and } \\
\text { Higher Education related to non vocation HEI ranking (Y2.26.) }\end{array}$ \\
\hline & $\begin{array}{l}\text { The number of Scopus indexed scientific articles per lecturer per year has met the minimum requirements } \\
\text { of the Kemenristek Dikti regarding non vocation HEI ranking (Y2.28.) }\end{array}$ \\
\hline
\end{tabular}
Source: (Pangarso, 2019c)

The HTMT detailed calculation results can be seen in Pangarso et al. (2020) show that the research variable have a good discriminant validity. After evaluating the measurement model, then proceed to the structural model evaluation process (inner model). Guidelines for structural evaluation models, according to J. F. J. Hair et al. (2017), consists of : VIF, R², $Q^{2}$ plus PLS predict (Shmueli et al., 2019) and IPMA.

Inner VIF detailed calculation results can be seen in in Pangarso et al. (2020) and show that all research variables are free from colinearity problems.

Smart PLS $\mathrm{R}^{2} \& \mathrm{Q}^{2}$ calculation detailed results can be seen in Pangarso et al. (2020) shows that the structural model has medium explanatory power and predictive relevance.

For PLS predict, the $\mathrm{Q}^{2}$ predict value for all indicators shows values above 0 means that the structural model has predictive power. Furthermore, the majority of the RMSE PLS values are smaller than the LM RMSE value, which means that the structural model has moderate predictive accuracy (Shmueli et al., 2019).

Table 3. Smart PLS PLS predict

\begin{tabular}{|c|c|c|c|}
\hline \multirow{2}{*}{} & \multirow{2}{*}{ PLS Q $^{2}$ predict } & \multicolumn{2}{|c|}{ RMSE } \\
\cline { 3 - 4 } & & PLS & LM \\
\hline Y1.1 & 0.477 & 0.604 & 0.601 \\
\hline Y1.6 & 0.410 & 0.558 & 0.564 \\
\hline Y1.8 & 0.468 & 0.537 & 0.545 \\
\hline Y1.9 & 0.461 & 0.558 & 0.571 \\
\hline Y1.7 & 0.317 & 0.592 & 0.606 \\
\hline Y1.5 & 0.498 & 0.592 & 0.596 \\
\hline Y2.20 & 0.379 & 0.666 & 0.666 \\
\hline Y2.26 & 0.320 & 0.633 & 0.644 \\
\hline Y2.28 & 0.360 & 0.655 & 0.642 \\
\hline Y2.17 & 0.306 & 0.684 & 0.673 \\
\hline
\end{tabular}




\begin{tabular}{|c|l|l|l|}
\hline Y2.18 & 0.401 & 0.598 & 0.591 \\
\hline Y2.25 & 0.350 & 0.615 & 0.608 \\
\hline Y2.9 & 0.339 & 0.702 & 0.678 \\
\hline Y2.21 & 0.373 & 0.612 & 0.618 \\
\hline Y2.24 & 0.298 & 0.630 & 0.639 \\
\hline
\end{tabular}

Source: Smart PLS PLS predict calculation result

The results of processing smart PLS data via bootstrap 5000 samples (Hair et al., 2017) shows that all hypotheses are accepted, both the significance and relevance of the path coefficient indicate a p-value of less than 0.05 . From Pangarso et al. (2020), it can be seen that the direct impact with the biggest coefficient is the positive impact of the absorption capacity on innovation ambidexterity. Absorptive capacity is proven to have a positive impact on sustainable competitive advantage both directly and indirectly through the mediation of innovation ambidexterity. Since all path coefficient values are positive, the impact of mediation innovation ambidexterity is in the category of partial complementary mediation (Hair et al., 2017). The smart PLS hyphotheses testing calculation results can be seen in Pangarso et.al (2020).

Table 4. Hypothesis testing result

\begin{tabular}{|c|c|}
\hline Hypothesis & Supported \\
\hline $\mathrm{H} 1$ & Yes \\
\hline $\mathrm{H} 2$ & Yes \\
\hline $\mathrm{H} 3$ & Yes \\
\hline \multicolumn{2}{|c|}{ Source: Pangarso et al. (2020) } \\
\hline
\end{tabular}

From the IPMA graphic image in Figure $5 \& 6$ also Table 5, it is found that the contribution of performance and importance of the variable absorptive capacity and innovative ambidexterity to sustainable competitive advantage is well-positioned. Still, the innovation ambidexterity variable has an essential role beyond absorptive capacity. Meanwhile, if viewed from the perspective of the indicator, all indicators of innovation ambidexterity variables appear to have a critical influence function on the sustainable competitive advantage that exceeds almost all indicators of absorptive capacity.

Table 5. IPMA calculation

\begin{tabular}{|c|c|c|}
\hline & LV Index & LV Performance \\
\hline Absorptive Capacity & 3.791 & 69.767 \\
\hline Innovation Ambidexterity & 3.805 & 70.118 \\
\hline Sustainable Competitive Advantage & 3.721 & 68.029 \\
\hline
\end{tabular}

Source: Smart PLS IPMA calculation result 


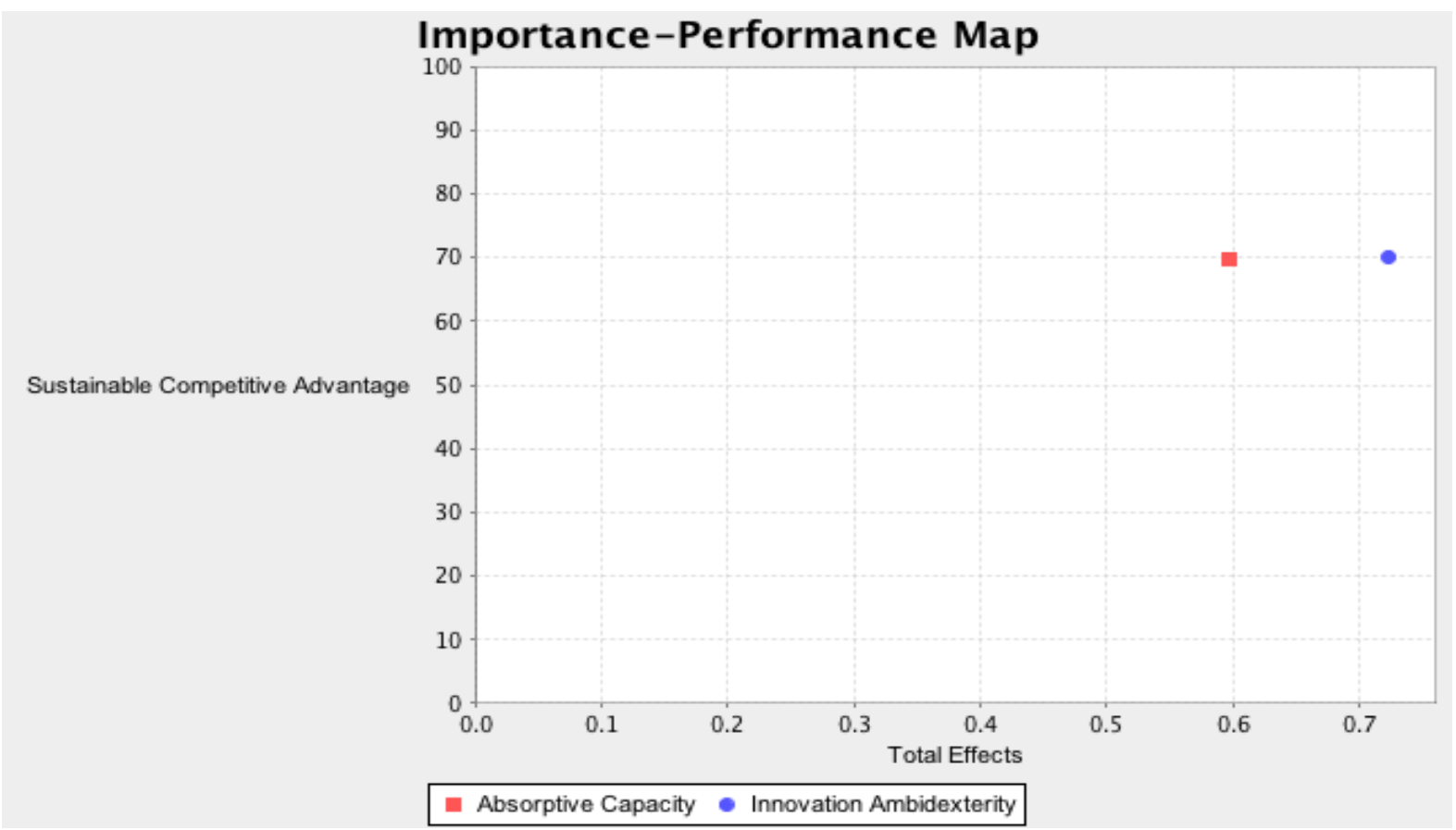

Figure 5. Smart PLS IPMA graphic result for variables Source: smart PLS IPMA calculation result

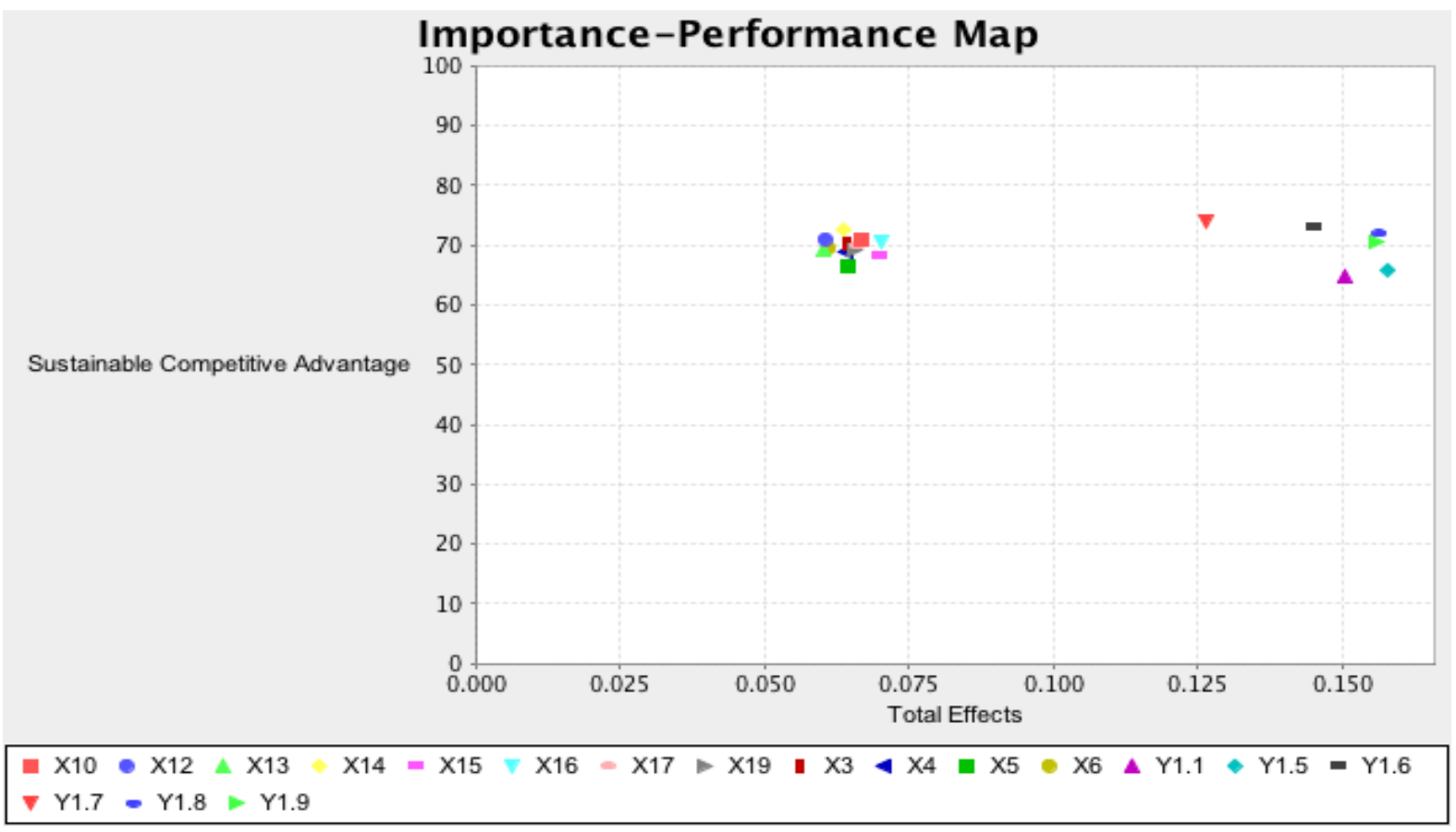

Figure 6. Smart PLS IPMA graphic result for indicators Source: smart PLS IPMA calculation result 


\section{ENTREPRENEURSHIP AND SUSTAINABILITY ISSUES}

ISSN 2345-0282 (online) http://jssidoi.org/jesi/

2020 Volume 7 Number 3 (March)

http://doi.org/10.9770/jesi.2020.7.3(65)

\section{Discussion}

All research hypotheses are proven to be support (Pangarso et al., 2020). This is because statistically, it can be seen that the p-value of each hypothesis is below 0.05; more precisely, all hypotheses have a p-value of 0 either directly or indirectly impacts. In addition to the p-value significance also see the statistical value whose value must be above 1.96. The $t$ value of statistics for all hypotheses shows that it has been more than 1.96. The hypothesis with the most excellent influence value is on $\mathrm{H} 1$, then $\mathrm{H} 2$ and $\mathrm{H} 3$, respectively. This is due to the value of the $\mathrm{H} 1$ path coefficient, which has the most exceptional value compared to other hypotheses.

The implications of the results of this data processing consist of theoretical and practical implications. The theoretical implications of this study also clarify the process of influence between absorptive capacity on sustainable competitive advantage. The indirect impact of absorptive capacity on sustainable competitive advantage through mediation innovation ambidexterity supports the theory of absorptive capacity and dynamic capability. By increasing the ability of an organization to absorb external knowledge, it influences the increase in innovation produced by exploration and exploitation to create a sustainable competitive advantage for non vocation PHEIs.

The positive and direct impact of absorptive capacity on innovation ambidexterity supports the theory of dynamic capability (that absorption capacity is part of dynamic capability and also innovation is the outcome of absorptive capacity). Empirical findings on the impact of absorptive capacity on innovation ambidexterity have filled the research gap Jurksiene \& Pundziene (2016). The ability of an organization to absorb knowledge from the outside to be applied internally is proven to increase innovation produced by organizations both obtained exploitatively and exploratively. The practical implication related to this finding is that PHEIs are advised to pay close attention and examine the condition of its absorptive capacity. Part of the absorptive capacity with the highest value loading factor is "the organization can use and exploit new knowledge from outside." The importance of private universities to be able to gain new knowledge from outside and use it for the realization of innovation. PHEIs are expected to 'open themselves' in collaboration with various parties outside their organizations, primarily related to the latest knowledge both online and offline. Whereas the most part of innovation with the loading factor is "Incrementally (gradually) increasing the reliability of research results and knowledge transfer." HEI innovation is more exploitative than explorative. PHEIs can gradually produce reliable research, and after that, the research results can be disseminated both academically and publicly. To be able to increase the impacts of constant study and spread gradually, it is also related to the opening of relations with parties outside the campus. Universities and colleges actively both online and offline participate in activities directly related to improving the quality of research and publications, specially with industry. This is important because this is where a transfer of knowledge from outside to inside and vice versa will be realized so it can directly influence the quality of research and publication.

The positive direct impact of innovation ambidexterity on sustainable competitive advantage supports the theory of dynamic capability. The findings of the empirical influence of innovation ambidexterity on sustainable competitive advantage have filled the research gap of research Preda (2014) also Jurksiene \& Pundziene (2016). With increasingly simultaneous innovations produced both exploitatively and exploratively, it has been proven to increase sustainable competitive advantage. The practical implication is that private universities need to pay attention and provide incremental and radical innovation. However, the emphasis of innovation here tends to be incremental rather than radical because the number of innovation indicators that pass the loading factor test is more exploitative (incremental) than explorative (radical). Innovations obtained through the process of exploitation from within the organization (internally) gradually by modifying existing innovations. This exploitative innovation also results in an increasingly sustainable competitive advantage. The highest value of loading factor sustainable competitive advantage is in the item "ISO HEI certification." ISO certification has detailed indicators that are recommended to be met by a tertiary institution. If the organization has innovated both 


\section{ENTREPRENEURSHIP AND SUSTAINABILITY ISSUES}

ISSN 2345-0282 (online) http://jssidoi.org/jesi/

2020 Volume 7 Number 3 (March)

http://doi.org/10.9770/jesi.2020.7.3(65)

exploratory and exploitative, then it can contribute to the realization of an organization having ISO certification. If a college has certification ISO 21001:2018 ("ISO - ISO 21001:2018 - Educational organizations — Management systems for educational organizations - Requirements with guidance for use," n.d.) clearly, this is a guarantee of the quality of a PHEI. If a private university has received the ISO certification, it is likely that the national ranking of the Ministry of Research and Technology (Kemenristek Dikti) can also be fulfilled, and can even be included in ranking 1 cluster. The challenge related to this ISO is the need for substantial financial resources, which not all PHEIs have because an essential part of the ISO standard that is met is in terms of physical infrastructure.

From the introduction, it can be seen that from a total of 250 PHEIs in the West Java province, only 7 entered 100 HEI rankings in Indonesia. It can be assumed that only seven PHEIs have a sustainable competitive advantage. Bandung region is considered sufficient to represent the West Java province, the Bandung region data can be used to capture the conditions of the West Java province. Data obtained from the Higher Education National Data Provider Forlap shows that 18 PHEIs in Bandung are categorized as "big" while 63 others are in the "small" category. This categorization is seen from the total number of students. PHEI, which is categorized as "big", is assumed to have more considerable resources than "small" so that there is a higher chance of having a sustainable competitive advantage. The seven PHEIs referred to fall into the "big" category. It is a challenge for the existing "small" private higher education institution with limited resources to have the ability to absorb knowledge from the outside to further produce innovation from the exploitation process so that it can enter the national ranking in Indonesia (has a sustainable competitive advantage). Specific challenges for managing foundations, leaders of the "small" campus, and LLDIKTI (Indonesian Private Higher Education Administrator Institution) (Pangarso, 2019a) to realize the ability of absorptive capacity that can produce innovation ambidexterity. Open science is expected to contribute and be an alternative solution to the problem of limited financial resources experienced by "small" PHEIs. This opens an opportunity for future research on the role of open science practices to improve the impactiveness of "small" PHEI's knowledge administration and competitiveness.

\section{Conclusions}

This research provides the answer to the research question of whether or not innovation ambidexterity mediates the impact of absorptive capacity on sustainable competitive advantage. It is clear from this research that innovation ambidexterity plays a partial role in mediating those two variables. Since this research only applied to non-vocational PHEIs, future research that include both non-vocational and vocational PHEIs is needed to give a better understanding on the PHEIs in Indonesia. The research model of this study allows to be tested in the future with a structural model with a Higher-Order / Second Order (HCM) since it has a sufficient number of indicators and have theoretical background. In addition, the organizational environment dynamics and knowledge infrastructure are two interesting variables to be both theoretically and empirically studied in the future in the links between absorptive capacity and sustainable competitive advantage.

\section{References}

Afrianty, T. W., Burgess, J., \& Theodora, I. (2015). Family-friendly support programs and work family conflict among Indonesian higher education employees. Equality, Diversity and Inclusion: An International Journal, 34(8), 2015. https://doi.org/10.1108/EDI-04-2015-0026

Apriliyanti, I. D., \& Alon, I. (2017). Bibliometric analysis of absorptive capacity. International Business Review, $26(5)$, 896-907. https://doi.org/10.1016/j.ibusrev.2017.02.007

Ávila, L. V., Leal Filho, W., Brandli, L., Macgregor, C. J., Molthan-Hill, P., Özuyar, P. G., \& Moreira, R. M. (2017). Barriers to innovation and sustainability at universities around the world. Journal of Cleaner Production, 164, 1268-1278. https://doi.org/10.1016/j.jclepro.2017.07.025

Barney, J. (1991). Firm Resources and Sustained Competitive Advantage. Journal of Management, 17(1), 99-120. https://doi.org/10.1177/014920639101700108 


\section{ENTREPRENEURSHIP AND SUSTAINABILITY ISSUES}

ISSN 2345-0282 (online) http://jssidoi.org/jesi/

2020 Volume 7 Number 3 (March)

http://doi.org/10.9770/jesi.2020.7.3(65)

Biro Kerjasama dan Komunikasi Publik, \& Kemenristekdikti. (2018). President Jokowi: Speed is the Key to Winning Competition in the Revolutionary Era 4.0 - Ristekdikti (Presiden Jokowi: Kecepatan Kunci Utama Memenangkan Kompetisi di Era Revolusi 4.0 Ristekdikti). Retrieved October 12, 2018, from https://ristekdikti.go.id/kabar/presiden-jokowi-kecepatan-kunci-utama-memenangkankompetisi-di-era-revolusi-4-0/

Blarr, W. H. (2012). Organizational Ambidexterity Implications for the Strategy- Performance Linkage. http://sci-hub.tw/10.1007/978-3$\underline{8349-6859-3}$

Burton, R. M., Eriksen, B. H., Håkonsson, D. D., Knudsen, T., \& Snow, C. C. (2008). Designing Organizations 21st Century Approaches. https://doi.org/10.1007/978-3-319-10996-1

Chang, Y. C., Yang, P. Y., Martin, B. R., Chi, H. R., \& Tsai-Lin, T. F. (2016). Entrepreneurial universities and research ambidexterity: A multilevel analysis. Technovation, 54, 7-21. https://doi.org/10.1016/j.technovation.2016.02.006

Child, J. (2015). Organization: Contemporary principles and practice: Second edition. Organization: Contemporary Principles and Practice: Second Edition. https://doi.org/10.1002/9781119176862

Cohen, W., \& Levinthal, D. (2004). Economic security for a better world. Indian Journal of Labour Economics, 47(3), 601-607. https://doi.org/10.2307/2393553

Cohen, W. M., \& Levinthal, D. A. (1990). Absorptive Capacity: A New Perspective on and Innovation Learning. Administrative Science Quarterly, 35(1), 128-152.

Cresswell, J. W. (2014). Research Design. Qualitative, Quantitative and Mixed methods approaches. Research Design Qualitative Quantitative and Mixed Methods Approaches. https://doi.org/10.1007/s13398-014-0173-7.2

Enkel, E., Heil, S., Hengstler, M., \& Wirth, H. (2016). Technovation Exploratory and exploitative innovation: To what extent do the dimensions of individual level absorptive capacity contribute? Technovation, (August 2015 ), 0-1. https://doi.org/10.1016/j.technovation.2016.08.002

Fernando, Y., \& Chukai, C. (2018). Research in Transportation Business \& Management Value Co-Creation , Goods and Service Tax ( GST ) Impacts on Sustainable Logistic Performance. Research in Transportation Business \& Management, (October), 0-1. https://doi.org/10.1016/j.rtbm.2018.10.001

Gibson, C. B., \& Birkinshaw, J. (2004). Antecedents, consequences, and mediating: Role of organizational ambidexterity. Academy of Management Journal, 47(2), 209-226. https://doi.org/10.2307/20159573

Girdzijauskaite, E., Radzeviciene, A., \& Jakubavicius, A. (2019). Impact of international branch campus KPIs on the university competitiveness: FARE method. Insights into Regional Development, 1(2), 171-180. https://doi.org/10.9770/ird.2019.1.2(7)

Hair, J. F. J., Hult, G. T. M., Ringle, C. M., \& Sarstedt, M. (2017). A Primer on Partial Least Squares Structural Equation Modeling (PLSSEM). Second edition. https://doi.org/10.1016/j.lrp.2013.01.002

Ismunandar. (2019). Plan Of Development And Innovation Of Online Learning (Rencana Pengembangan dan Inovasi Pembelajaran Daring). https://docplayer.info/135116408-Rencana-pengembangan-dan-inovasi-pembelajaran-daring-meningkatkan-relevansi-mutu-danakses-ismunandar-semarang-4-januari-2019.html

Jabar, B. (2016). Jawa Barat dalam angka. Retrieved http://pusdalisbang.jabarprov.go.id/pusdalisbang/berkas/jabardalamangka/747Provinsi-Jawa-Barat-Dalam-Angka-2016.pdf

Jansen, J.J.P. (2005, April 29). Ambidextrous Organizations: A Multiple-Level Study of Absorptive Capacity, Exploratory and Exploitative Innovation and Performance (No.55). ERIM Ph.D. Series Research in Management. Erasmus University Rotterdam. Retrieved from hdl.handle.net/1765/6774

Jurksiene, L., \& Pundziene, A. (2016). The relationship between dynamic capabilities and firm competitive advantage: the mediating role of organizational ambidexterity. European Business Review, 28(4). https://doi.org/http://dx.doi.org/10.1108/EBR-09-2015-0088

Kemenristekdikti. (2018a). Indicators and Clustering Data of 2017 Kemenristekdikti Higher Education Institutions | Directorate General of Science and Technology Institution and Higher Education Institutions (Indikator dan Data Klasterisasi Perguruan Tinggi Kemenristekdikti 


\section{ENTREPRENEURSHIP AND SUSTAINABILITY ISSUES}

ISSN 2345-0282 (online) http://jssidoi.org/jesi/

2020 Volume 7 Number 3 (March)

http://doi.org/10.9770/jesi.2020.7.3(65)

Tahun 2017 | Direktorat Jenderal Kelembagaan Iptek dan Dikti). Retrieved August 7, 2018, from http://kelembagaan.ristekdikti.go.id/index.php/2017/08/17/indikator-dan-data-klasterisasi-perguruan-tinggi-kemenristekdikti-tahun-2017/

Kemenristekdikti. (2018b). Kemenristekdikti Announces Ranking of Top 100 Non Vocational Indonesian Higher Education Institutions in 2018 - Ristekdikti (Kemenristekdikti Umumkan Peringkat 100 Besar Perguruan Tinggi Indonesia Non Vokasi Tahun 2018 - Ristekdikti). Retrieved August 18, 2018, from https://ristekdikti.go.id/kemenristekdikti-umumkan-peringkat-100-besar-perguruan-tinggi-indonesia-nonvokasi-tahun-2018/

Kementerian Riset, Teknologi, Dan P. T. (2017). (Indonesian Higher Education Institutions Clusterization in 2017). https://www.ristekdikti.go.id/kabar/kemenristekdikti-umumkan-klasterisasi-perguruan-tinggi-indonesia-tahun-2017/

Keuangan, K. (2019a). Advetorial RAPBN 2020. Acceleration of Competitiveness through Innovation and Strengthening the Quality of Human Resources (Akselerasi Daya Saing melalui Inovasi dan Penguatan Kualitas Sumber Daya Manusia). https://www.kemenkeu.go.id/publikasi/siaran-pers/siaran-pers-apbn-untuk-mengakselerasi-daya-saing-melalui-inovasi-dan-penguatan-

kualitas-sumber-daya-manusia/

Keuangan, K. (2019b). Indonesia's Strategy in Facing World Economic Turbulence (Strategi Indonesia Menghadapi Turbulensi Perekonomian Dunia). https://www.slideshare.net/chatronik/strategi-indonesia-menghadapi-turbulensi-perekonomian-dunia-2020

Klinger, N. (2016). Organizational Ambidexterity and Absorptive Capacity. Otago Management Graduate Review, 14, 21-30. https://doi.org/http://dx.doi.org/10.1016/j.jaad.2012.12.211

Kohlbacher, M., Weitlaner, D., Hollosi, A., Grahsl, H., \& Gru, S. (2013). Innovation in clusters: impacts of absorptive capacity and environmental moderators. Competitiveness Review: An International Business Journal, 23(3), 199-217. https://doi.org/10.1108/10595421311319807

Koran Sindo. (n.d.). Telkom University The Number One Private University in Indonesia (Telkom University Peringkat Pertama PTS di Indonesia). Retrieved September 11, 2019, from https://nasional.sindonews.com/read/1432277/144/telkom-university-peringkat-pertamapts-di-indonesia-1566445944

Kortmann, S. (2012). The relationship between organizational structure and organizational ambidexterity: Manufacturing vs. service firms. 10.1007/978-3-8349-3630-1

Kortmann, Sebastian. (2015). The Mediating Role of Strategic Orientations on the Relationship between Ambidexterity-Oriented Decisions and Innovative Ambidexterity. Journal of Product Innovation Management, 32(5), 666-684. https://doi.org/10.1111/jpim.12151

Lee, H. K., \& Fernando, Y. (2015). The antecedents and outcomes of the medical tourism supply chain. Tourism Management, 46, 148157. https://doi.org/10.1016/j.tourman.2014.06.014

Li, C. (2013). How top management team diversity fosters organizational ambidexterity. Journal of Organizational Change Management, 26(5), 874-896. https://doi.org/10.1108/JOCM-06-2012-0075

Liao, J., Welsch, H., \& Stoica, M. (2003). Organizational Absorptive Capacity and Responsiveness: An Empirical Investigation of GrowthOriented SMEs. Entrepreneurship Theory and Practice, 28(1), 63-86. https://doi.org/10.1111\%2F1540-8520.00032

Limaj, E., \& Bernroider, E. W. N. (2017). The roles of absorptive capacity and cultural balance for exploratory and exploitative innovation in SMEs. Journal of Business Research, (October), 0-1. https://doi.org/10.1016/j.jbusres.2017.10.052

March, J. G. (1991). Exploration and Exploitation in Organizational Learning. Organization Science, 2(1), 71-87. https://doi.org/10.1287/orsc.2.1.71

Mardi, M., Arief, M., Furinto, A. et al. J Knowl Econ (2018) 9: 1049. http://sci-hub.tw/10.1007/s13132-016-0385-5

Mariano, S., \& Walter, C. (2015). The construct of absorptive capacity in knowledge management and intellectual capital research: content and text analyses. Journal of Knowledge Management, 19(2), 372-400. https://doi.org/10.1108/JKM-08-2014-0342

Martinez-Conesa, I., Soto-Acosta, P., \& Carayannis, E. G. (2017). On the path towards open innovation: assessing the role of knowledge management capability and environmental dynamism in SMEs. Journal of Knowledge Management, 21(3), 553-570. https://doi.org/10.1108/JKM-09-2016-0403 


\section{ENTREPRENEURSHIP AND SUSTAINABILITY ISSUES}

ISSN 2345-0282 (online) http://jssidoi.org/jesi/

2020 Volume 7 Number 3 (March)

http://doi.org/10.9770/jesi.2020.7.3(65)

Menteri Riset, P., \& Pendidikan Tinggi, D. (n.d.). The Minister Of Research, Technology, And Higher Education Of The Republic Of Indonesia (Menteri Riset, Teknologi, Dan Pendidikan Tinggi Republik Indonesia). Retrieved from https://forlap.ristekdikti.go.id/files/download/MTM

Miles, J. A. (2012). Management and Organization Theory. Jossey Bass. https://www.wiley.com/enus/Management+and+Organization+Theory\%3A+A+Jossey+Bass+Reader-p-9781118008959

Nasional/Bappenas, K. P. P. (2019). Draft Indonesian Vision 2045 and Indonesian Dream 2015-2085 (Draft Visi Indonesia 2045 dan Impian Indonesia 2015-2085). https://ditjenpdt.kemendesa.go.id/index.php/download/getdata/Draft_Ringkasan_Eksekutif_Visi_Indonesia_2045_7_November_2018.pdf

Nasir, M. (2019). CONCLUSION RI's 74th Anniversary Commemoration in 2019 "Excellent HR, Advanced Indonesia." (Sambutan Peringatan HUT Ke-74 RI Tahun 2019 "SDM Unggul, Indonesia Maju.") Retrieved from https://www.ristekdikti.go.id/wpcontent/uploads/2019/08/Sambutan-HUT-RI-2019_Menristekdikti_final.pdf

Newhart, M., \& Patten, M. L. (2018). Understanding Research Methods: An Overview of the Essentials. Taylor \& Francis.

Noni, I. De, Ganzaroli, A., Orsi, L., \& Roberta, A. (2013). Innovation, Absorptive Capacity, Environmental Complexity, Trust and Cooperation within Clusters. Review of Integrative Business \& Economics, 2(1), 276-291. https://pdfs.semanticscholar.org/516e/6007a1e1d5646ad49814a5f54662435623f2.pdf

Nora, L. D. D., Siluk, J. C. M., Júnior, A. L. N., Soliman, M., Nara, E. O. B., \& Furtado, J. C. (2016). The performance measurement of innovation and competitiveness in the telecommunications services sector. International Journal of Business Excellence, 9(2), 210-224. https://doi.org/10.1504/IJBEX.2016.074844

Nowak, R. (2017). Demystifying Absorptive Capacity: Focus on Firm Size and Employee Empowerment. International Journal of Innovation Management, 21(06), 1750050. https://doi.org/10.1142/S1363919617500505

O'Reilly, C. A., \& Tushman, M. L. (2008). Ambidexterity as a dynamic capability: Resolving the innovator's dilemma. Research in Organizational Behavior, 28, 185-206. https://doi.org/10.1016/j.riob.2008.06.002

Organization, A. P., \& Pannen, P. (2017). Productivity in Higher Education Research insights for universities and governments in Asia. https://www.apo-tokyo.org/publications/wp-content/uploads/sites/5/eReport-Productivity in Higher Education Oct2017.pdf

Pangarso, A. (2014). Organization's structure based on competing value approach and merger strategy. In Proceedings of 20142 nd International Conference on Technology, Informatics, Management, Engineering and Environment, TIME-E 2014. https://doi.org/10.1109/TIME-E.2014.7011616

Pangarso, A. (2016). Lecturer sociometric badge as digital platform in Indonesia higher education institutions from organizational impactiveness perspective. Advanced Science Letters, 22(12). https://doi.org/10.1166/asl.2016.8134

Pangarso, Astadi. (2019a). The use of Sociometric Badge for Lecturers in Indonesia related to the impactiveness of Higher Education organizations for the sake of Golden Indonesia (Penggunaan Sociometric Badge bagi Dosen di Indonesia terkait efektivitas organisasi Perguruan Tinggi demi Indonesia Emas). Retrieved November 2, 2019, from https://doi.org/10.6084/m9.figshare.9730034.v1

Pangarso, Astadi. (2019b, March). How to improve the quality of private universities, where the majority of Indonesian students study (Bagaimana meningkatkan kualitas universitas swasta, tempat mayoritas mahasiswa Indonesia kuliah). Retrieved March 15, 2019, from https://theconversation.com/bagaimana-meningkatkan-kualitas-universitas-swasta-tempat-mayoritas-mahasiswa-indonesia-kuliah111520 ?fbclid=IwAR014qfb-wg1 miLTBu3WOkDUz 6Rrtuzof uK2invQrO0xCv0GTzyURWD8Q https://doi.org/10.6084/m9.figshare.9730034.v1

Pangarso, A., Astuti, E. S., Raharjo, K., \& Afrianty, T. W. (2020). Data of innovation ambidexterity as a mediator in the absorptive capacity impact on sustainable competitive advantage. Data in Brief, 105200. https://doi.org/10.1016/j.dib.2020.105200

Pengetahuan, D. J. K. I. (2015). Academic Classification And Improvement of Indonesia Higher Education 2015 (Naskah Akademik Klasifikasi dan Pemeringkatan Perguruan Tinggi Indonesia Tahun 2015). Retrieved from https://ristekdikti.go.id/wpcontent/uploads/2016/03/Naskah-Akademik-KPPT2015-2.pdf

Podsakoff, P. M., MacKenzie, S. B., \& Podsakoff, N. P. (2012). Sources of Method Bias in Social Science Research and Recommendations on How to Control It. Annual Review of Psychology, 63(1), 539-569. https://doi.org/10.1146/annurev-psych-120710-100452 


\section{ENTREPRENEURSHIP AND SUSTAINABILITY ISSUES}

ISSN 2345-0282 (online) http://jssidoi.org/jesi/

2020 Volume 7 Number 3 (March)

http://doi.org/10.9770/jesi.2020.7.3(65)

Prajogo, D. I., \& Oke, A. (2016). Human capital, service innovation advantage, and business performance: The moderating roles of dynamic and competitive environments. International Journal of Operations and Production Management, 36(9), 974-994. https://doi.org/10.1108/IJOPM-11-2014-0537

Preda, G. (2014). Organizational Ambidexterity And Competitive Advantage: Toward a Research Model. Management \& Marketing, XII(1), 67-74.

Raghuvanshi, J., Ghosh, P. K., \& Agrawal, R. (2019). Taxonomy of innovation capability framework with future directions. International Journal of Business Excellence, 17(3), 265-289. https://doi.org/10.1504/IJBEX.2019.097958

Raharjo, K., \& Fernandes, A. A. R. (2018). The influence of organizational culture and job design on job commitment and human resource performance. Journal of Organizational Change Management, JOCM-07-2017-0286. https://doi.org/10.1108/JOCM-07-2017-0286

Ratna, S., Astuti, E., Utami, H., Rahardjo, K. and Arifin, Z. (2018), "Characteristics of tasks and technology as a driver of task-technology fit and the use of the hotel reservation information system", VINE Journal of Information and Knowledge Management Systems, Vol. 48 No. 4, pp. 579-595. https://doi.org/10.1108/VJIKMS-05-2018-0035

Rao, I., \& Thakur, P. (2019). Knowledge workers, organisational ambidexterity and sustainability: A conceptual framework. International Journal of Business Excellence, 19(3), 415-428. https://doi.org/10.1504/IJBEX.2019.102832

Republic Indonesia, T. P. of. Republic of Indonesia Presidential Regulation number 72 of 2019 concerning the Ministry of Education and Culture (Peraturan Presiden Republik Indonesia nomor 72 Tahun 2019 tentang Kementrian Pendidikan dan Kebudayaan) (2019). https://www.kemdikbud.go.id/main/blog/2019/10/peraturan-presiden-republik-indonesia-nomor-72-tahun-2019-tentang-kemendikbud

Ringle, C. M., Wende, S., and Becker, J.-M. (2015). "SmartPLS 3." Boenningstedt: SmartPLS GmbH, http://www.smartpls.com

Saatcioglu, Omur. (2016). Profiling innovation research in social sciences citation index (2009-2014). International Journal of Organizational $\quad$ Leadership. $5.40-49$. https://www.researchgate.net/publication/294705172 Profiling innovation research in social sciences citation index 2009$\underline{2014 / \text { citations }}$

Salgues, B. (2018). Society 5.0 Industry of the Future, Technologies, Methods and Tools. Wiley (Vol. 1). https://www.wiley.com/enus/Society+5+0\%3A+Industry+of+the+Future $\% 2 \mathrm{C}+$ Technologies $\% 2 \mathrm{C}+$ Methods+and+Tools-p-9781119527633

Schumpeter, J. (2003). Capitalization, Socialism and democracy. $\underline{\text { https://doi.org/10.2307/1058736 }}$

Seftiawan, D. (2018). Hanya 5 PTS di Jabar yang Siap Bermitra dengan Perguruan Tinggi Asing | Pikiran Rakyat. Retrieved August 4 , 2018, from http://www.pikiran-rakyat.com/pendidikan/2018/02/01/hanya-5-pts-di-jabar-yang-siap-bermitra-dengan-perguruan-tinggiasing-418660

Shahriari, M., Abzari, M., Isfahani, A. N., \& Kianpour, M. (2018). The impact of high performance work systems on radical innovation in knowledge-based companies through moderating role of innovation capabilities. International Journal of Business Excellence, 16(3), 269285. https://doi.org/10.1504/IJBEX.2018.095635

Shmueli, G., Sarstedt, M., Hair, J. F., Cheah, J. H., Ting, H., Vaithilingam, S., \& Ringle, C. M. (2019). Predictive model assessment in PLS-SEM: guidelines for using PLSpredict. European Journal of Marketing. https://doi.org/10.1108/EJM-02-2019-0189

Simsek, Z. (2009). Organizational ambidexterity: Towards a multilevel understanding. Journal of Management Studies, 46(4), 597-624. https://doi.org/10.1111/j.1467-6486.2009.00828.x

Soto-Acosta, P., Popa, S., \& Martinez-Conesa, I. (2018). Information technology, knowledge management and environmental dynamism as drivers of innovation ambidexterity: a study in SMEs. Journal of Knowledge Management, 22(4), 824-849. https://doi.org/10.1108/JKM$\underline{10-2017-0448}$

Statistik, B. P. (2018). Indonesian population by provinces 1971, 1980, 1990, 1995, 2000 and 2010 (Penduduk Indonesia menurut Provinsi 1971, 1980, 1990, 1995, 2000 dan 2010). Retrieved August 7, 2018, from https://www.bps.go.id/statictable/2009/02/20/1267/pendudukindonesia-menurut-provinsi-1971-1980-1990-1995-2000-dan-2010.html

Teece, D. J., Pisano, G., \& Shuen, A. (1997). Dynamic capabilities and strategic management. Strategic Management Journal, 18(7), 509533. https://doi.org/10.1002/(Sici)1097-0266(199708)18:7<509::Aid-Smj882>3.0.Co;2-Z 


\section{ENTREPRENEURSHIP AND SUSTAINABILITY ISSUES}

ISSN 2345-0282 (online) http://jssidoi.org/jesi/

2020 Volume 7 Number 3 (March)

http://doi.org/10.9770/jesi.2020.7.3(65)

Templin, C. (1999). Hillary Clinton as threat to gender norms: Cartoon images of the first lady. Journal of Communication Inquiry, 23(1), 20-36. https://doi.org/10.1177/0196859999023001002

Valmohammadi, C., \& Ahmadi, M. (2015). The impact of knowledge management practices on organizational performance. Journal of Enterprise Information Management, 28(1), 131-159. https://doi.org/10.1108/JEIM-09-2013-0066

Vera, D., Crossan, M., \& Apaydin, M. (2003). A Framework for integrating organizational learning, knowledge, capabilities, and absorptive capacity. Blackwell Handbook of organizational learning and knowledge management. https://doi.org/10.1002/9781119207245.ch8

Wernerfelt, B. (1984). A resource-based view of the firm. Strategic Management Journal, 5(2), 171-180. https://doi.org/10.1002/smj.4250050207

Xing, Y., Liu, Y., Boojihawon, D. K., \& Tarba, S. (2019). Entrepreneurial team and strategic agility: A conceptual framework and research agenda. Human Resource Management Review, 100696. https://doi.org/10.1016/j.hrmr.2019.100696

Zahra, S. A., \& George, G. (2002). Absorptive Capacity: a Review, and Extension. Academy of Management Review, 27(2), 185-203. https://doi.org/10.5465/APBPP.2000.5438568

Zang, J., \& Li, Y. (2017). Technology capabilities, marketing capabilities and innovation ambidexterity. Technology Analysis and Strategic Management, 29(1), 23-37. https://doi.org/10.1080/09537325.2016.1194972

Zhang, J. A., \& Cui, X. (2017). In search of the impacts of business and political ties on innovation ambidexterity. International Journal of Innovation Management, 21(02), 1750019. https://doi.org/10.1142/S1363919617500190

Zhang, J. A., Edgar, F., Geare, A., \& O'Kane, C. (2016). The interactive impacts of entrepreneurial orientation and capability-based HRM on firm performance: The mediating role of innovation ambidexterity. Industrial Marketing Management, 59, 131-143. https://doi.org/10.1016/j.indmarman.2016.02.018

Zhang, M., Zhao, X., \& Lyles, M. (2018). Impacts of absorptive capacity, trust and information systems on product innovation. International Journal of Operations and Production Management, 38(2), 493-512. https://doi.org/10.1108/IJOPM-11-2015-0687

Zou, T., Ertug, G., \& George, G. (2018). The capacity to innovate: a meta-analysis of absorptive capacity. Innovation: Management, Policy and Practice, 20(2), 87-121. https://doi.org/10.1080/14479338.2018.1428105

\section{Aknowledgements}

This research was supported by LPDP (Indonesia Endownment Fund for Education) as a research funder and LPPM Telkom University as a publication funder, Indonesia

\section{Appendix}

Supplementary data to this article:

Pangarso, Astadi (2019c), "Questionnaire data of innovation ambidexterity, absorptive capacity and sustainable competitive advantage", Mendeley Data, v2 https://data.mendeley.com/datasets/z2y8gmxtrb/3

Astadi PANGARSO is a doctoral candidate at Brawijaya University, Indonesia. He is also an assistant professor at Telkom University, Bandung, Indonesia and teaches organization theory and organization behavior. His dissertation research focus in sustainable competitive advantage organization study (from perspectives of innovation, knowledge and ambidexterity). His duties in this study are: Conceptualization; Methodology; Investigation; Writing - Original Draft; Writing - Review \& Editing. Research interests: Organization Theory, Organization Studies.

ORCID ID: orcid.org/0000-0001-9189-0122 


\section{ENTREPRENEURSHIP AND SUSTAINABILITY ISSUES}

ISSN 2345-0282 (online) http://jssidoi.org/jesi/

2020 Volume 7 Number 3 (March)

http://doi.org/10.9770/jesi.2020.7.3(65)

Endang Siti ASTUTI is a Professor of Information Technology System at Brawijaya University, Indonesia. At the Faculty of Administrative Science, she teaches management of information system; entrepreneurship and innovation management; information technology governance; strategic information system. She is well known as an expert in management of information system, technology and innovation. Her duties in this study are: Conceptualization; Methodology; Writing - Review \& Editing; Supervision.

ORCID ID: orcid.org/0000-0003-3283-7342

Kusdi RAHARJO is an Associate Professor at Brawijaya University, Indonesia. At the Faculty of Administrative Science, he teaches entrepreneurship and innovation management; human resource management and organization theory. He is well known as an expert in organization studies and competitive advantage. His duties in this study are: Conceptualization; Methodology; Writing - Review \& Editing; Supervision.

ORCID ID: orcid.org/0000-0003-4319-0644

Tri Wulida AFRIANTY is an Assistant Professor at Brawijaya University, Indonesia. At the Faculty of Administrative Science, she teaches human resource management and organization behavior. She is well known as an expert in workfamily balance study. Her duties in this study are: Conceptualization; Methodology; Writing - Review \& Editing; Supervision.

ORCID ID: orcid.org/0000-0002-8746-4718

Copyright (C) 2020 by author(s) and VsI Entrepreneurship and Sustainability Center

This work is licensed under the Creative Commons Attribution International License (CC BY).

http://creativecommons.org/licenses/by/4.0/

cC) (7) Open Access 